\title{
Incidence of cancer and mortality among workers exposed to mercury vapour in the Norwegian chloralkali industry
}

\author{
Dag G Ellingsen, Aage Andersen, Hans P Nordhagen, Jon Efskind, Helge Kjuus.
}

\begin{abstract}
Incidence of cancer and mortality were studied among 674 men exposed to mercury vapour for more than one year at two chloralkali plants. Mercury excretion in urine had been monitored among the workers at the two plants since 1948 and 1949. An individual cumulative urinary mercury dose was calculated, based on about 20000 urinary mercury measurements. The incidence of cancer and the mortality were followed up from 1953 to 1989 and 1953 to 1988 respectively. The general Norwegian male population served as a reference population. There was a lung cancer excess of borderline significance (standardised incidence ratio $=1.66,95 \%$ confidence interval $=1 \cdot 00-2 \cdot 59)$. The introduction of a 10 year latent period before developing lung cancer did not increase the incidence ratio. The excess may be partly explained by the smoking habits in the cohort or possibly by exposure to asbestos. No excess of cancer was found in the target organs for mercury toxicity-namely, the kidney and the nervous system. No significant excess mortality was found for nephritis and nephrosis or nonmalignant diseases of the nervous system.
\end{abstract}

(British fournal of Industrial Medicine 1993;50:875-880)

Some chloralkali plants utilise liquid mercury as a cathode in the electrolysis of brine when producing

Department of Occupational Medicine, Telemark Central Hospital, N-3906 Porsgrunn, Norway

D G Ellingsen, $\mathrm{H}$ Kjuus

Cancer Registry of Norway, Montebello, N-0310 Oslo, Norway

A Andersen

The Health Department, Hydro Porsgrunn, N-3900 Porsgrunn, Norway

H P Nordhagen

The Health Department, Borregaard Industries Ltd, N-1700 Sarpsborg, Norway

$\mathrm{J}$ Efskind chlorine and caustic soda. Release of mercury vapour into the working atmosphere may occur, and thus constitute a hazard to the worker's health.

Elemental mercury may penetrate the bloodbrain barrier. Most of the inhaled mercury vapour is oxidised, however, to divalent mercury in the blood. Inorganic mercury is mainly eliminated by urinary and faecal excretion. ${ }^{1}$

Excess incidence of chromosomal aberrations among subjects exposed to mercury as compared with unexposed subjects has been found. ${ }^{2}$ Other cytogenetic studies in chloralkali workers exposed to mercury vapour have, however, not shown any chromosomal damage. ${ }^{34}$

There are only a few reports from animal studies on the possible carcinogenic effects of inorganic mercury. ${ }^{56}$ In mice given mercuric chloride added to the drinking water, no statistically significant excess in the prevalence of tumours was found compared with control animals. ${ }^{7}$ Metallic mercury was injected intraperitoneally in a study in rats, and five out of 12 animals developed peritoneal sarcomas. ${ }^{8}$

An excess mortality of non-malignant genitourinary tract diseases was found among employees in electrolytic mercury cell rooms compared with unexposed factory workers. ${ }^{9}$ An American study ${ }^{10}$ showed a non-significant excess of deaths from lung cancer among workers exposed to inorganic mercury in a plant producing enriched lithium, but the authors did not relate the excess mortality to exposure to mercury. A census investigation among dentists and dental nurses in Sweden showed an excess of brain cancer, and amalgam was suggested as one possible causative compound. ${ }^{11}$ Finally, in a study on mortality and the incidence of cancer among workers in the Swedish chloralkali industry, ${ }^{12}$ a slightly increased mortality from cardiovascular diseases was found. The incidence of lung cancer was also in excess, and previous exposure to asbestos was suggested as a possible causative exposure factor.

The aim of the present study was to investigate the mortality and incidence of cancer among 
workers in the Norwegian chloralkali industry, scrutinising the possibility that exposure to mercury vapour could be a determinant for diseases resulting in cancer or death. As the main target organs for the toxic effects of inorganic mercury are the central nervous system and the kidneys, these organs have been considered in detail.

\section{Material and methods}

THE PLANTS

Two Norwegian plants have used the mercury cell process to produce chlorine and caustic soda. Brine is electrolysed in cells where the cathode is a thin flowing layer of liquid mercury. Chlorine is produced, and sodium from the brine is amalgamated with mercury. A counter flow of water meets the amalgam in a secondary cell. Caustic soda and hydrogen gas are produced, and the amalgamated mercury is regenerated to its original liquid state. Graphite anodes were used until the second half of the 1970 s, when they were replaced by titanium anodes. Each cell contained about 1000 to $2000 \mathrm{~kg}$ mercury, and there were more than 100 cells in each plant. Plant A started production in 1947 and plant B in 1949. Both plants are situated in industrialised urban areas in southeast Norway.

\section{SUBJECTS}

The subjects were identified from three sources; the files of the company personnel units, the records from the company health departments, and lists of results from the urinary mercury surveillance of the workers. The urinary mercury results were complete from 1952 in plant A and 1963 in plant B. Nearly all urinary mercury measurements before 1952 were found in the company health department records in plant $A$. The results from about 3000 urinary mercury measurements before 1963 were found in the medical department records in plant B.

Time of employment and job state were ascertained from the accessible sources together with interviews with older employees. The medical records were also used to obtain information on smoking habits, exposure to asbestos, and chlorine intoxications.

Men employed for more than one year before 1989 were included in the cohort. Altogether, 802 subjects were identified. One subject could not be identified by the personal identification number assigned to all persons living in Norway, and two subjects died before 1953 and were thus excluded. The total cohort comprised 799 men, of whom 419 worked in plant $\mathrm{A}$ and 380 in plant $\mathrm{B}$.

\section{EXPOSURE ASSESSMENT}

Surveillance of the workers by determination of urinary mercury started in 1948 in plant $A$ and 1949 in plant B. Different modifications of the dithizone method were used until the mid-1970s, when cold vapour atomic absorption spectrophotometry was introduced. The frequency of urinary mercury determinations was two to four times a year for each worker in plant $A$ until the first half of the 1970 s and two to three measurements each year since then. In plant $B$ the frequency was one to four times each year for the entire period, depending on the job title.

A cumulative urinary mercury dose was calculated for each subject based on the quarterly mean individual urinary mercury concentration. If a subject had not delivered a urine specimen for analysis in a specific quarter, a substitute value was calculated from the mean values from two quarters before and after the missing period. The cumulative urinary mercury dose represents the sum of the mean individual urinary mercury excretion for each year employed. About 10000 urinary mercury measurements were identified among the workers in each of the plants.

\section{METHODS}

All incident cases of cancer in Norway have been recorded by the Cancer Registry of Norway since 1953. The registration is based on the compulsory reporting of all cancer cases by hospital departments, histopathological laboratories, and death certificates. About $1 \%$ of all cases are based on death certificates only. The cancer cases are coded according to the International Classification of Diseases, seventh revision (ICD-7).

All death certificates are coded by the Central Bureau of Statistics of Norway according to the existent versions of the ICD system. Information on deaths is transferred regularly to the Cancer Registry. Statistics on underlying causes of death have been published since the beginning of the century and computerised since 1951 .

Since 1960, all residents of Norway have a unique personal identification number, which permits the identification of the cases. Cases of cancer and death that occurred before 1960 were identified manually.

The observation period for mortality was 1953-88 and 1953-89 for incidence of cancer. The mortality and incidence of cancer were compared with the expected rates in the general Norwegian male population, based on the age specific national rates for five year age groups for each calendar year from 1953. The data analyses were restricted to 674 subjects who were employed for the first time before 1980 .

Standardised mortality ratios (SMRs) were calculated for the specific causes of death, and standardised incidence ratios (SIRs) were calculated for the incident cases of cancer. Ninety five per cent 
confidence intervals $(95 \% \mathrm{CIs})$ were calculated assuming a Poisson distribution of the observed cases.

\section{Results}

EXPOSURE

The mean time of employment among the 674 workers employed for the first time before 1980 was 9.6 (range 1.0-38.9) years, and their mean cumulative urinary mercury dose was $3700 \mathrm{nmol} / 1$ (range $25-22382, \mathrm{n}=657$ ). The individual mean urinary mercury concentration each year was 465 $\mathrm{nmol} / \mathrm{l}$ (range 8-2868 nmol/l, $\mathrm{n}=657$ ). There was a highly significant association between the number of years employed and cumulative urinary mercury dose (Pearson's $\mathrm{r}=0.69, \mathrm{p}<0.01, \mathrm{n}=657$ ). Nearly $30 \%$ of the subjects in the restricted cohort have at least once exceeded the urinary mercury concentration of $1500 \mathrm{nmol} / \mathrm{l}$ during their biological surveillance.
CANCER

Table 1 presents the observed $(\mathrm{O})$ and expected (E) cases of cancer, based on the observation of 16633 person-years. Eighty nine cancers were observed $v 85.02$ expected. A borderline significant excess of lung cancer was found $(\mathrm{O} / \mathrm{E}=19 / 11 \cdot 47$, SIR $=1 \cdot 66,95 \%$ CI $1 \cdot 00-2 \cdot 59)$. Two cancers had occurred in the nervous system $v 2.45$ expected. In the kidney, three cancers were found $v 3.17$ expected. One pleural mesothelioma was found (not tabulated), diagnosed in the $1980 \mathrm{~s}$ in a bricklayer. Before 1940 he had repaired furnaces insulated with asbestos at another plant. No cases of leukaemia (ICD 7: 204) were found $v 2 \cdot 16$ expected (not tabulated).

We found no significantly increased SIRs when the cohort was analysed according to duration of employment (table 2). The highest SIR for lung cancer was among workers employed for 5-14 years $(\operatorname{SIR}=2 \cdot 05)$. Both cases of cancer of the nervous

Table 1 Observed $(O)$ and expected $(E)$ cases of cancer at selected sites among 674 male chloralkali workers first employed before 1980. Observation period 1953-89.

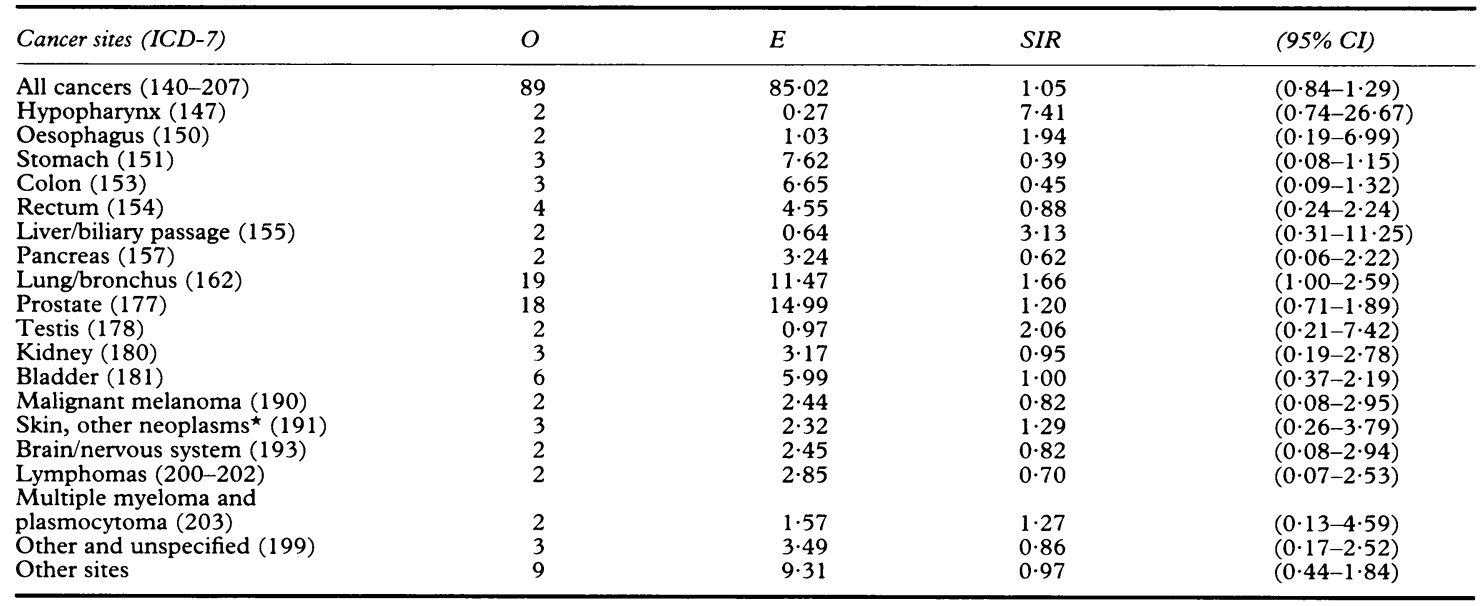

^Excludes basal cell carcinoma.

Table 2 Observed $(O)$ and expected $(E)$ cases of cancer at selected sites among 674 male chloralkali workers by duration of mercury exposure. Observation period 1953-89.

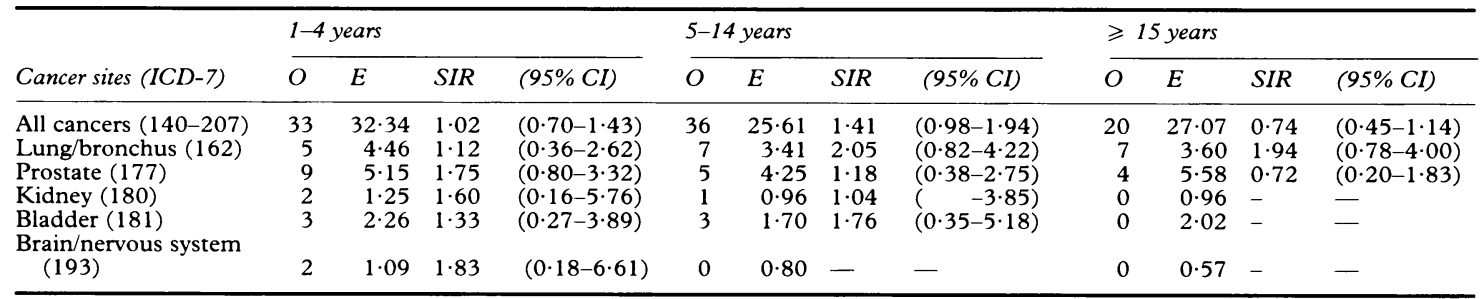


Table 3 Observed $(O)$ and expected $(E)$ cases of cancer at selected sites among 674 male chloralkali workers by time since first employment. Observation period 1953-89.

\begin{tabular}{|c|c|c|c|c|c|c|c|c|}
\hline \multirow[b]{2}{*}{ Cancer sites (ICD-7) } & \multicolumn{4}{|c|}{$<10$ years } & \multicolumn{4}{|c|}{$\geqslant 10$ years } \\
\hline & $O$ & $E$ & SIR & $(95 \% C I)$ & $O$ & $E$ & $S H R$ & $(95 \% C I)$ \\
\hline $\begin{array}{l}\text { All cancers (140-207) } \\
\text { Lung/bronchus (162) } \\
\text { Prostate (177) } \\
\text { Kidney }(180) \\
\text { Bladder (181) } \\
\text { Brain/nervous system (193) }\end{array}$ & $\begin{array}{r}16 \\
2 \\
0 \\
0 \\
1 \\
2\end{array}$ & $\begin{array}{r}10 \cdot 56 \\
1 \cdot 33 \\
0.94 \\
0 \cdot 42 \\
0.53 \\
0.58\end{array}$ & $\begin{array}{l}1.52 \\
1.50 \\
- \\
1.89 \\
3.45\end{array}$ & $\begin{array}{l}(0 \cdot 86-2 \cdot 46) \\
(0 \cdot 15-5 \cdot 41) \\
- \\
(\quad-10 \cdot 57) \\
(0 \cdot 34-12 \cdot 41)\end{array}$ & $\begin{array}{r}73 \\
17 \\
18 \\
3 \\
5 \\
0\end{array}$ & $\begin{array}{r}74 \cdot 46 \\
10 \cdot 13 \\
14 \cdot 05 \\
2 \cdot 75 \\
5 \cdot 46 \\
1 \cdot 88\end{array}$ & $\begin{array}{l}0.98 \\
1.68 \\
1.28 \\
1.09 \\
0.92 \\
-\end{array}$ & $\begin{array}{l}(0 \cdot 77-1 \cdot 23) \\
(0 \cdot 98-2 \cdot 69) \\
(0 \cdot 76-2 \cdot 02) \\
(0 \cdot 22-3 \cdot 20) \\
(0 \cdot 29-2 \cdot 14) \\
-\end{array}$ \\
\hline
\end{tabular}

system were found among subjects employed for less than five years. Two cases of kidney cancer were also found in this subgroup, and one case was a worker employed for eight years.

The cohort was also analysed according to time since first employment, thus allowing for the possibility of a development time before the occurrence of an exposure related cancer (table 3). Both cancers of the nervous system occurred less than 10 years after first employment. The three kidney cancers occurred more than 10 years after first employment. Seventeen lung cancers were found more than 10 years after first employment $v 10 \cdot 13$ expected (SIR $=1 \cdot 68,95 \%$ CI 0.98-2.69). Twelve lung cancers were found $v 7 \cdot 04$ expected (SIR = $1 \cdot 70$ ) when a latency time of more than 20 years was introduced.

The subjects with renal cancer had a cumulative urinary mercury dose of about $1100 \mathrm{nmol} / \mathrm{l}, 3300$ $\mathrm{nmol} / \mathrm{l}$, and $4400 \mathrm{nmol} / \mathrm{l}$ respectively. None of them had a recorded urinary mercury value exceeding $1500 \mathrm{nmol} / \mathrm{l}$ during the time of employment. One of the subjects with cancer of the nervous system had been employed for nearly five years, but no urinary mercury measurements were found for this worker. The other case had a cumulative urinary mercury dose of nearly $500 \mathrm{nmol} / 1$ and no recorded urinary spot sample exceeding $500 \mathrm{nmol} / \mathrm{l}$ during the time of exposure.

\section{MORTALITY}

The results from selected causes of death are based on 16170 person-years. Altogether, 204 deaths were observed $v 210.67$ expected (table 4). None of the calculated SMRs differed significantly from unity. Among the 674 workers, there were two deaths from nephritis and nephrosis and four deaths from Diseases of the nervous system and sense organs. Exact expected rates for these causes of death were calculated from 1962 only, and were 1.03 and 2.83 respectively. Expected rates for the period 1953-61 were estimated to half the expected values of the following nine year period from 1962-70. This procedure was chosen due to the technical difficulties in obtaining expected figures for the entire period. The mortality from lung can- cer (not tabulated) was followed up through 1989 $(\mathrm{O} / \mathrm{E}=15 / 10 \cdot 34, \quad \mathrm{SMR}=1 \cdot 45, \quad 95 \% \quad \mathrm{CI}$ $0 \cdot 81-2 \cdot 39$ ).

In all, 197 subjects in the restricted cohort had been under medical treatment for chlorine intoxication at least once, but no increased mortality from non-malignant lung diseases was found.

Table 5 presents some selected causes of death related to the duration of employment. A nearly significant deficit of deaths due to all cardiovascular diseases was found among subjects exposed for more than 15 years. Introduction of a latent period for death of $10-19$ or $\geqslant 20$ years after first employment did not increase the SMR for the same causes of death (table 6).

The diagnosis among the four subjects who died from non-malignant diseases of the nervous system were all different. Their cumulative urinary mercury doses were about $700,1600,2000$, and 8500 $\mathrm{nmol} / \mathrm{l}$ respectively. One of them had exceeded $1500 \mathrm{nmol} / \mathrm{l}$ urine on urinary spot samples. For both cases of death due to nephritis or nephrosis the cause of death was classified as chronic

Table 4 Observed (O) and expected $(E)$ cases of selected causes of death among 674 male chloralkali workers first employed before 1980. Observation period 1953-88.

\begin{tabular}{|c|c|c|c|c|}
\hline $\begin{array}{l}\text { Cause of death } \\
\text { (ICD-7) }\end{array}$ & $O$ & $E$ & $S M R$ & $(95 \% C I)$ \\
\hline $\begin{array}{l}\text { All deaths } \\
\text { All }\end{array}$ & 204 & $\begin{array}{r}210 \cdot 67 \\
48 \cdot 88\end{array}$ & $\begin{array}{l}0.97 \\
1.04\end{array}$ & $\begin{array}{l}(0.84-1 \cdot 11) \\
(0.78-1.37)\end{array}$ \\
\hline Diseases of the circulatory & & & & \\
\hline $400-468)$ & 91 & $105 \cdot 15$ & 0.87 & $(0 \cdot 70-1 \cdot 06)$ \\
\hline $\begin{array}{l}\text { Arteriosclerotic and } \\
\text { degenerative heart } \\
\text { disease }(420-422)\end{array}$ & 67 & $71 \cdot 43$ & 0.94 & $(0 \cdot 73-1 \cdot 19)$ \\
\hline $\begin{array}{l}\text { Diseases of the respiratory } \\
\text { system }(470-527)\end{array}$ & 12 & $13 \cdot 89$ & 0.86 & $(0.45-1.51)$ \\
\hline Pneumonia $(490-493)$ & 6 & 6.93 & $0 \cdot 87$ & $(0 \cdot 32-1 \cdot 89)$ \\
\hline $\begin{array}{l}\text { Diseases of the digestive } \\
\text { system }(530-587)\end{array}$ & 4 & $5 \cdot 47$ & 0.72 & $(0 \cdot 20-1 \cdot 86)$ \\
\hline $\begin{array}{l}\text { Accidents, poisonings, } \\
\text { and violence (800-999) }\end{array}$ & 14 & $12 \cdot 77$ & $1 \cdot 10$ & $(0 \cdot 60-1 \cdot 84)$ \\
\hline $\begin{array}{l}\text { Nephritis, nephrosis } \\
\quad(590-594) \\
\text { Diseases of the nervous }\end{array}$ & 2 & $1 \cdot 20^{\star}$ & 1.67 & $(0 \cdot 17-6 \cdot 00)$ \\
\hline $\begin{array}{l}\text { system and sense } \\
\text { organs }(340-399)\end{array}$ & 4 & $3 \cdot 08^{\star}$ & $1 \cdot 30$ & $(0 \cdot 36-2 \cdot 86)$ \\
\hline
\end{tabular}

^Estimated values, see text. 
Table 5 Observed $(O)$ and expected $(E)$ cases of all deaths (0-999), diseases of the circulatory system (330-334, 400-468), and arteriosclerotic and degenerative heart diseases (420-422) among 674 chloralkali workers by time of employment. Observation period 1953-88.

\begin{tabular}{|c|c|c|c|c|c|c|c|c|c|c|c|}
\hline \multirow{2}{*}{$\begin{array}{l}\text { Cause of death } \\
\text { (ICD-7) }\end{array}$} & \multicolumn{4}{|c|}{$<5$ years } & \multicolumn{3}{|c|}{$5-14$ years } & \multicolumn{4}{|c|}{$\geqslant 15$ years } \\
\hline & $O$ & $E$ & $S M R$ & $(95 \% C I)$ & $O$ & $E$ & $S M R(95 \% C I)$ & $O$ & $E$ & $S I R$ & $(95 \% C I)$ \\
\hline \multirow{3}{*}{$\begin{array}{l}\text { All deaths (0-999) } \\
\text { Circulatory system } \\
(330-334,400-468) \\
\text { Arteriosclerotic/degenerative } \\
\text { heart disease }(420-422)\end{array}$} & 76 & $75 \cdot 33$ & $1 \cdot 01$ & $(0 \cdot 80-1 \cdot 26)$ & 68 & $65 \cdot 50$ & $1.04(0.81-1 \cdot 32)$ & 60 & $69 \cdot 85$ & 0.86 & $(0 \cdot 66-1 \cdot 11)$ \\
\hline & 34 & $36 \cdot 29$ & 0.94 & $(0 \cdot 65-1 \cdot 31)$ & 32 & $32 \cdot 45$ & $0.99 \quad(0.67-1.39)$ & 25 & $36 \cdot 41$ & 0.69 & $(0 \cdot 44-1 \cdot 01)$ \\
\hline & 22 & $25 \cdot 39$ & $0 \cdot 87$ & $(0.54-1.31)$ & 23 & 21.98 & $1.05(0.66-1.57)$ & 22 & 24.05 & 0.91 & $(0.57-1.38)$ \\
\hline
\end{tabular}

Table 6 Observed (O) and expected (E) cases of all deaths (0-999), diseases of the circulatory system (330-334, 400-468), and arteriosclerotic and degenerative heart diseases (420-422) among 674 chloralkali workers by time since first exposure. Observation period 1953-88.

\begin{tabular}{|c|c|c|c|c|c|c|c|c|c|c|c|}
\hline \multirow{2}{*}{$\begin{array}{l}\text { Cause of death } \\
\text { (ICD-7) }\end{array}$} & \multicolumn{4}{|c|}{$<10$ years } & \multicolumn{3}{|c|}{ 10-19 years } & \multicolumn{4}{|c|}{$\geqslant 20$ years } \\
\hline & $\mathbf{O}$ & $\mathbf{E}$ & SMR & $(95 \% \mathrm{CI})$ & O & $\mathbf{E}$ & SMR $(95 \% \mathrm{CI})$ & $\mathbf{O}$ & $\mathrm{E}$ & SMR & $(95 \% \mathrm{CI})$ \\
\hline \multirow{3}{*}{$\begin{array}{l}\text { All deaths }(0-999) \\
\text { Circulatory system } \\
(330-334,400-468) \\
\text { Arteriosclerotic/degenerative } \\
\text { heart disease }(420-422)\end{array}$} & 26 & $28 \cdot 07$ & 0.93 & $(0 \cdot 61-1 \cdot 36)$ & 54 & $55 \cdot 74$ & $0.97(0.73-1.26)$ & 124 & $126 \cdot 86$ & 0.98 & $(0 \cdot 81-1 \cdot 17)$ \\
\hline & 8 & $11 \cdot 72$ & 0.68 & $(0 \cdot 30-1 \cdot 35)$ & 23 & $27 \cdot 46$ & $0.84(0.53-1.26)$ & 60 & $65 \cdot 97$ & 0.91 & $(0 \cdot 69-1 \cdot 17)$ \\
\hline & 6 & $8 \cdot 58$ & $0 \cdot 70$ & $(0.26-1.53)$ & 19 & $19 \cdot 84$ & $0.96(0.57-1.50)$ & 42 & $43 \cdot 00$ & 0.98 & $(0 \cdot 70-1 \cdot 32)$ \\
\hline
\end{tabular}

nephritis. One of the subjects had a cumulative urinary mercury dose of $1900 \mathrm{nmol} / \mathrm{l}$ and died 17 years after cessation of exposure, the other died 20 years after the end of exposure, and had a cumulative urinary mercury dose of $3700 \mathrm{nmol} / \mathrm{l}$.

\section{Discussion}

The present study has focused on diseases with possible association with exposure to mercury vapour. The results from the biological monitoring are regarded as complete since 1948 in plant $A$ and 1963 in plant B. The physician in plant B reported that 3023. urinary mercury measurements had been performed from 1949 to the end of 1961 (G Mowé, personal communication). About 3000 urinary mercury results from plant B before 1963 are known to the investigators, indicating that nearly all workers under surveillance in both plants were included in the cohort.

A nearly significant excess of lung cancer $(\mathrm{O} / \mathrm{E}=$ $19 / 11.5)$ was found in the cohort. The excess was not significant among subjects exposed for more than 15 years $(\mathrm{O} / \mathrm{E}=7 / 3.6)$, and introduction of 10 years of latency did not increase the ratio $(\mathrm{O} / \mathrm{E}=$ $17 / 10 \cdot 1)$. Information on smoking habits obtained from the company health files was fairly complete since the mid-1970s, and was available for $59 \%$ of the total cohort. Among these, there were $56 \%$ current smokers, $20 \%$ never-smokers, and $24 \%$ exsmokers. The prevalence of current smokers among workers employed for the first time from 1970 to 1979 was $64 \%$. In a cross sectional study performed during 1989 among 86 subjects under 65 years of age and employed for more than one year in plant $\mathrm{A}, 56 \%$ reported to be current smokers, $23 \%$ ex-smokers, and $21 \%$ never smokers. Among Norwegian men the prevalence of daily smokers was $48 \%$ in 1975 , and $39 \%$ in $1986 .{ }^{13}$ The available smoking data suggest, at least since the 1970s, that the prevalence of smoking in the cohort was $15 \%-20 \%$ higher than in the reference population, although smoking was prohibited in the plants mainly due to possible leakage of hydrogen gas, and as a preventive measure against exposure to mercury vapour.

Asbestos has not been extensively used in the plants, but some asbestos was used for various maintenance purposes. Also, the workers may have been exposed to asbestos in other workplaces than the chloralkali plants, as indicated by one case of pleural mesothelioma with exposure to asbestos unrelated to the plants under study.

The assumed higher prevalence of smokers and the possibly higher prevalence of exposure to asbestos in the cohort compared with the reference population may, at least in part, explain the slight excess of lung cancer. The incidence of lung cancer in the two counties where the plants are located was between 90 and $110 \%$ of the national figures for the periods $1972-6$ and $1982-6 .{ }^{14}{ }^{15}$ Barregård $e t$ $a l^{12}$ found an excess of lung cancer in the Swedish chloralkali industry, which was possibly related to previous exposure to asbestos.

No excess cancer in the brain or nervous system and kidney was found in the present study. This is in accordance with the results from Barregård et 
al. ${ }^{12}$ Cragle et al ${ }^{10}$ found no excess mortality from cancers of the central nervous system or kidney among workers exposed to elemental mercury in an American plant producing enriched lithium. Ahlbom et al "11 found, however, an excess of glioblastoma among dentists and dental nurses in a Swedish study based on data given at census, which the authors suggested could be related to different aetiological factors in the work environment of the studied subjects. The exposure to mercury vapour among the cases of cancer of the kidney and brain or nervous system in the present study were low to moderate, and the duration of exposure was short.

None of the studied causes of death were significantly increased in the present study. A slightly increased mortality from cardiovascular disease, which was found among Swedish chloralkali workers, ${ }^{12}$ was not found in the present study. No significant excess mortality due to non-malignant diseases of the nervous system and sensory organs was found, which is in agreement with the Swedish chloralkali study. ${ }^{12}$ Cragle et al ${ }^{10}$ made similar observations in their study.

In a survey of death certificates among factory workers exposed to mercury for the periods 1945-60 and 1972-9, Duffield et al ${ }^{9}$ noted an excess of death from diseases of the genitourinary tract among mercury cell workers in the first period, but not in the second. Barregård et al ${ }^{12}$ reported one case of nephritis/nephrosis $(E=0.8)$ in their study. Cragle et al ${ }^{10}$ did not find any excess of deaths due to non-malignant renal diseases. In the present study, two cases of nephritis/nephrosis were found $(E=1 \cdot 2)$. Due to the widespread use of renal dialysis and transplantation, death may not be an appropriate measure, however, of outcome of renal diseases.

Exposure to chlorine is another major health hazard to workers in the chloralkali industry, and 197 subjects in the restricted cohort had at least once been under medical treatment for chlorine intoxication. Hence, it is of interest that no excess death due to non-malignant lung diseases was found. Traditionally however, it was difficult for subjects with known lung diseases to be employed at the two plants. This health selection implies that interpretation of the SMR concerning these diseases should be made with caution. Comparable SMRs for non-malignant lung diseases were found by Cragle $e t a^{10}$ and Barregård et al. ${ }^{12}$

In a Swedish study ${ }^{16}$ from a chloralkali plant that used cells with a direct current of $100 \mathrm{kA}$, static magnetic fields in the range of 4 millitesla (mT) to $29 \mathrm{mT}$ were measured. The cells in the plants included in the present study were smaller for most of the period, and no information about the strength of the static magnetic fields in the plants under study are known to the investigators. Altogether, there were four cases of neoplasms in lymphatic and haematopoietic tissues (ICD-7: 200-205) v 6.59 expected (SIR $=0.61,95 \%$ CI $0 \cdot 17-1 \cdot 55)$.

We found no relation between exposure to mercury vapour and cancer in the present study. Nor did the investigation reveal any relation between mercury exposure and the studied causes of death. The study was based on small numbers, however, and the results should be interpreted with caution.

We thank Patricia Flor for her linguistic help.

The study was carried out with financial support from Norsk Hydro A/S, Norway.

Requests for reprints to: Dag G Ellingsen, Department of Occupational Medicine, Telemark Central Hospital, N-3906 Porsgrunn, Norway.

1 Berlin M. Mercury. In: Friberg L, Nordberg GF, Vouk VB, eds. Handbook on the toxicology of metals. Vol 2. Amsterdam: Elsevier, 1986:387-445.

2 Popescu HI, Negru L, Lancranjan I. Chromosome aberrations induced by occupational exposure to mercury. Arch Environ Health 1979;34:461-3.

3 Mabille V, Roels H, Jacquet P, Léonard A, Lauwerys R. Cytogenetic examination of leucocytes of workers exposed to mercury vapour. Int Arch Occup Environ Health 1984; 53:257-60.

4 Verschaeve L, Tassignon JP, Lefevre M, De Stoop P, Susanne C. Cytogenetic investigation on leukocytes of workers exposed to metallic mercury. Environ Mutagen 1979;1: 259-68.

5 Kazantzis G. Role of cobalt, iron, lead, manganese, mercury, platinum, selenium, and titanium in carcinogenesis. Environ Health Perspect 1981;40:143-61.

6 World Health Organisation (WHO). Environmental Health Criteria 118. Inorganic mercury. Geneva, WHO, 1991.

7 Schroeder HA, Mitchener M. Life-term effects of mercury, methyl mercury, and nine other trace metals on mice. $\mathcal{F}$ Nutr 1975;105:452-8.

8 Druckrey H, Hamperl H, Schmähl D. Cancerogene Wirkung von metallischem Quecksilber nach intraperitonealer Gabe bei Ratten. Z Krebsforsch 1957;61:511-9. (In German).

9 Duffield DP, Paddle GM, Woolhead G. A mortality study of non-malignant genitourinary tract disease in electrolytic mercury cell room employees. F Soc Occup Med 1983; 33:137-40.

10 Cragle DL, Hollis DR, Qualters JR, Tankersley WG, Fry SA. A mortality study of men exposed to elemental mercury. 7 Occup Med 1984;26:817-21.

11 Ahlbom A, Norell S, Rodvall Y, Nylander M. Dentists, dental nurses, and brain tumours. $B M F$ 1986;292:662.

12 Barregård L, Sällsten G, Järvholm B. Mortality and cancer incidence in chloralkali workers exposed to inorganic mercury. Br ₹ Ind Med 1990;47:99-104.

13 Lund KE. Tobakksforbruk og røykevaner i Norge. Tidsskrift om edruskapssporsmål 1987;3:15-17. (In Norwegian).

14 The Cancer Registry of Norway. Incidence of cancer in Norway 1972-76. Oslo: The Norwegian Cancer Society, 1978.

15 The Cancer Registry of Norway. The incidence of cancer in Norway 1982-86. Oslo: The Cancer Registry of Norway, 1989.

16 Barregård L, Järvholm B, Ungethüm E. Cancer among workers exposed to strong static magnetic fields. Lancet 1985; ii: 892 .

Accepted 30 November 1992 